\title{
China's Belt and Road Initiative: Opportunities and Challenges for Georgia
}

\section{Nino Kemoklidze *}

Kemoklidze, N. (2021). China's Belt and Road Initiative: Opportunities and Challenges for Georgia. Lex Portus, 7 (2), 64-105. https://doi.org/10.26886/2524-101X.7.2.2021.4

*University of Chichester (College Lane, Chichester, PO19 6PE, United Kingdom) https://orcid.org/0000-0002-5294-7277 (c) 90 This work is licensed under a Creative Commons Attribution-

\section{ABSTRACT}

The article explores China's growing presence and activities in Georgia and its present and potential geopolitical implications. Its aim is to contribute to the better understanding of China's Belt and Road Initiative and its impact on the socio-political and economic security in Georgia as well as wider Caucasus region more generally. The article highlights Georgia's role in the BRI as a land and maritime "bridge". It examines in some depth the role of the Trans-Caspian route - the so-called Middle Corridor and its constituting Baku-Tbilisi-Kars (BTK) railway in the future development of the BRI and Georgia's involvement in it as a "logistics hub" connecting Asia and Europe. The article also explores the prospects of the Deep-Water Port Project in the Black Sea town of Anaklia in Georgia and why it has not materialised yet. It touches upon the conflicting interests of Russia, Turkey and the US and how geopolitics influences economic calculations of the project. The article is 
largely based on a desk research conducted in summer and autumn 2020 and utilises both secondary and primary sources in its analysis. Online interviews and author's communication with the Georgian government officials, Embassy representatives, experts in the field, Georgian exchange students in China and others connected to Chinese companies in Georgia have also been used in the analysis presented in the article. The article shows how despite increased Chinese involvement in Georgia more generally, China's interest in the development of the economically, and possibly politically strategic for Georgia "Middle Corridor" route remains rather lukewarm. However, as the article tries to demonstrate, this should not prevent Georgia to pursue its ambitious plan of becoming a connecting land and maritime hub in the region. China is undoubtedly an important player in Asia and beyond, but it is not the only player.

The key words: Belt and Road Initiative, China-Georgia relations, "Middle Corridor", Baku-Tbilisi-Kars railway, Anaklia port.

\section{Introduction}

Next year, on 9 June 2022, Georgia and the People's Republic of China will be celebrating the $30^{\text {th }}$ anniversary of the establishment of diplomatic relations. In the past decade or so in particular, the relations between the two countries have grown significantly. At present, Georgia is the only country in the region with preferential trade regimes with two of the largest economic areas in the worldthe Deep and Comprehensive Free Trade Area (DCFTA) with the European Union (EU) ${ }^{1}$ and the Free Trade Agreement (FTA) with China ${ }^{2}$. Both agreements have been dubbed as 'historic' in Georgia (Georgia, EU Sign Association Agreement; Georgia, China Sign Historic Free Trade Agreement). In addition, Georgia

${ }^{1}$ The DCFT with the EU and the four members of the European Free Trade Association - Iceland, Liechtenstein, Norway and Switzerland, officially came into force on 1 July 2016 but had been provisionally applied since 1 September 2014 (for more on this see: Countries and Regions: Georgia).

2 The FTA with China, signed on 13 May 2017, officially came into force on 1 January 2018 . At the time Georgia was only the $11^{\text {th }}$ country to have concluded such an agreement with China (Georgia is the Only Country in the Region Which has Free Trade Agreements with Both the EU and China). For more on the FTA, see: China-Georgia FTA). 
also boasts free trade agreements with Turkey ${ }^{1}$ and eight members of the Commonwealth of Independent States (CIS) - Azerbaijan, Armenia, Ukraine, Belarus, Moldova, Kazakhstan, Uzbekistan and Turkmenistan (Georgia is the Only Country in the Region Which has Free Trade Agreements with Both the EU and China). As many have pointed out, this puts Georgia in a rather "unique position" (Larsen, 2017c; author's interviews, July-Aug. 2020).

Since the 2003 'Rose Revolution', Georgia's foreign policy direction has been steadily Western oriented, and Georgia had openly declared its ambition of Euro-Atlantic integration. However, this has not prevented it from seeking economic ties in the East as well. While Georgia's rapprochement with the EU and its inclusion in the DCFTA has not surprised many of the Georgia-watchers, announcement of the launch of the FTA negotiations with China in 2015 proved to be a 'shocking event' even for those directly involved in the negotiation processes (Georgia Can Still be a Hub for China, But Only if the Belt \& Road Survives; author's interviews, July-Aug. 2020). In 2016 Georgia also got directly involved in China's ambitious Belt and Road Initiative (BRI) after becoming the $45^{\text {th }}$ country to join the Asian Infrastructure Investment Bank (AIIB) - "a USD 100 billion bank designed to funnel money into BRI projects" (Larsen, 2017a; see also: PM Discusses GeorgiaChina Partnership at Beijing University). At the time, some even dubbed these developments as the 'peak' of the Sino-Georgian relations (Topuria, 2016).

Indeed, in the years preceding these events, Chinese presence and activities in Georgia had seen a steady growth: China had gradually become one of Georgia's most important trading partners and one of its biggest investors, contributing significantly to its Foreign Direct Investment (FDI). For instance, in 2014, Chinese investment

1 Georgia and Turkey signed the agreement on 21 November 2007 and the FTA entered into force on 1 November 2008 (Free Trade Agreements: Georgia). For more on this, see: Free Trade Agreement, 2007. 
in Georgia amounted to $\$ 217$ million - "more than in all previous years combined" (Larsen, 2017a). As China's Ambassador to Georgia Ji Yanchi pointed out at the time, "[a]t the beginning of our diplomatic relations, the trade turnover stood at 3.68 million USD whereas, in 2016 it reached 717 million USD, growing 200 times" (cited in: China-Georgia Friendship Celebrates the 25th Anniversary of Diplomatic Relations).

Cultural ties between the two countries were also on the rise. In 2010, Confucius Institute was launched at Free University of Tbilisi in order to facilitate cultural exchanges between China and Georgia and promote Chinese language and culture (Georgia Opens its Confucius Institute) ${ }^{1}$. Since then dozens of Georgian students have been offered the Chinese Government Scholarships every year to continue their studies at the universities across China (author's interviews, July-Aug. 2020). In fact, by 2017, Ambassador Ji Yanchi boasted to have had "more than a thousand local Chinese speaking students" in Georgia (China-Georgia Friendship Celebrates the 25th Anniversary of Diplomatic Relations). By the end of 2019 a second Confucius Institute was established at Tbilisi Open Teaching University $^{2}$. The flow of Chinese tourists to Georgia had also grown, reportedly increasing by $46 \%$ in 2016 (China-Georgia Friendship Celebrates the 25th Anniversary of Diplomatic Relations). This was not surprising. As Georgia's Prime Minister Irakli Gharibashvili remarked during his speech at Peking University in 2015, "[t]here is no country in the region that is more open to Chinese business and investment, Chinese people and culture or Chinese innovation and ideas than Georgia" (PM Discusses Georgia-China Partnership at Beijing University).

${ }^{1}$ For more about Confucius Institute see: About Confucius Institute/Classroom. For a concise list of Confucius Institutes Around the World see: Confucius Institutes Around the World - 2020. For more about Confucius Institute at Free University of Tbilisi see: Confucius Institute at Free University of Tbilisi; Confucius Institute.

2 See: Confucius Institute at Tbilisi Open Teaching University. 
The two countries also seem to take a similar stance on important matters of concern for both states such as sovereignty and territorial integrity. Georgia supports China's so-called One-China policy on the issue of Taiwan (China and Georgia), and more recently Hong Kong (Aghmosavletis margaliti' didkhans ikashkashebs). Similarly, China has refused to follow Russia's footsteps and recognise Georgia's two break away territories (Abkhazia and South Ossetia) as independent (Larsen, 2017a) ${ }^{1}$. In other words, as China's then Ambassador noted, the two countries have enjoyed "an exemplary model of friendly ... relations" (China-Georgia Friendship Celebrates the 25th Anniversary of Diplomatic Relations).

Despite a lot of scepticism about the future of the Sino-Georgian relations and the prospects for Georgia, these positive developments also gave way to a lot of enthusiasm in Georgia, both among the policymakers as well as experts (Cecire, 2015; Topuria, 2016; Larsen, 2017c). Many predicted that China was on course of becoming "a genuine, and likely long-term, player in Georgia and the South Caucasus" (Cecire, 2015). As one analyst pointed out at the time, it is not Georgia's quest to join the EU or the North Atlantic Treaty Organisation (NATO), or its unresolved territorial conflicts and strained relations with its northern neighbour that should be the main focus. Rather, "if you really want to get to know Georgia", one should "pay attention to its deepening relationship with China" (Larsen, 2017c).

Besides the more obvious economic gains, for some, there was an even a bigger reason to be hopeful for growing ties with China (Topuria, 2016). It was believed that greater Chinese engagement in the region had a potential to influence "Russia's strategic calculus by increasing the cost of destabilising" its neighbouring countries,

${ }^{1}$ China has generally disapproved any unilateral action that might undermine state sovereignty, whether it was in the case of Kosovo or the cases of Abkhazia and South Ossetia. But it does so also out of the fear of possible secessionist movements on its own territory, as some have remarked, fearing the change of "the status of Xinjiang or Tibet, not to mention Taiwan" (Ferdinand, 2013, p. 24). 
including Georgia, and in this way ease Russia's "geopolitical pressure" on the region (Larsen, 2017b, p. 4; see also: Topuria, 2016, Galbreath $\&$ Malyarenko, 2020). While most analysts agreed that it was unlikely for Georgia to play “a key strategic or security" role in China's foreign policy in any near future, some argued that Georgia could potentially "punch above its weight" and use certain advantages as a leverage, in particular, "its unique geographic location as a bridge between Europe and Asia" (Larsen, 2017b, p. 4). Others were more cautions and were far more concerned about the possible security challenges posed by China's growing presence in the region (author's interviews, JulyAug. 2020). Some even admit now that their earlier projections might have been overly optimistic (author's interview with Revaz Topuria ${ }^{1}$, 16 July 2020; see also: Topuria, 2019).

So, what are the reasons for China's growing interest in Georgia a country with a substantial geographic distance from China and of a significantly small size both in terms of its population and its land?2 (China-Land Area (sq. Km)). How did Georgia go from being "barely on China's radar" when the One Belt One Road (OBOR) was first announced in $2013^{3}$ to signing the FTA with China in 2017? (Larsen, 2017c). Where do the Georgia-China relations stand now: are we witnessing an end to the "diplomatic honeymoon" (Topuria, 2019) between the two countries or an emergence of a Chinese political strategy in Georgia (or the wider Caucasus)? Can Georgia gain more from China's involvement in the region other than economic cooperation? What is the impact of the current fall-out between China and the West and the so-called US-China Trade War on SinoGeorgian relations? What might be the potential socio-political and economic security implications for Georgia and beyond if Chinese

${ }^{1}$ Georgia-based independent analyst.

2 Population of Georgia is less than four million as opposed to China's population of nearly 1.5 billion. In terms of the territory, Georgia covers 69,700 sq.km. while China covers 9,388,210 sq.km. (China - Land Area (sq. Km)).

3 Until 2016 the BRI was known as OBOR, or New Silk Road (Belt and Road Initiative; Duchâtel et al., 2016). 
"business turns political"? (Larsen, 2017a). And what kind of impact might China's greater involvement have on the sustainable stability in the region more generally? These are some of the questions that this paper will highlight and try to answer.

The main aim of the article is to provide a detailed analysis of the development of the Georgia-China relations and the current state of affairs. The article will map China's presence in Georgia and its main activities and will outline some of the main (current and potential future) geopolitical implications of its engagement in the region. In this way, the article aims to contribute to the growing scholarly and policy interest in China's involvement in the Caucasus and provide a better understanding of its BRI and Georgia's role in it more specifically.

\section{Methodology}

The article is largely based on secondary sources but some primary sources in the form of online interviews were also used. Online interviews with some key interlocutors and stakeholders from Georgia were conducted in July-August 2020. Other sources include official documents, statements and press releases by both governments supplemented by secondary sources, including academic literature, policy papers and briefs, as well as news reports and other online sources in English, Georgian, and Russian languages.

The article starts with a brief outline of China-Georgia economic relations before moving on to a detailed discussion of the BRI and an in-depth examination of Georgia's present and potential future role in it. Next, the article turns to the analysis of China's presence in Georgia, what it means for both countries and the wider region as well as some of the other important players in the South Caucasus. The article discusses some of the possible challenges that might accompany China's greater engagement with Georgia and offers some concluding remarks on how Georgia could maximize China's presence in the region and minimize potential risks. 
This article draws on findings from a research project investigating the implications of China's Belt and Road Initiative for the OSCE conducted by the OSCE Network of Think Tanks and Academic Institutions and funded by the German Federal Ministry of Foreign Affairs. The project objectives include: mapping the presence of China and its manifestation across Central Asia, the South Caucasus, the Western CIS, and the Western Balkans over time, in particular since the inception of the BRI; identifying the implications that this presence has had in terms of economic, environmental, social, political, and military security in the OSCE area (China's Belt and Road Initiative: Implications for the OSCE).

\section{China-Georgia economic relations}

Therelations between China and Georgia have grown exponentially since the establishment of bilateral relations in 1992. Cooperation has been particularly strong in the economic sphere, with a focus on FDI and trade. As Georgia's economy emerged from the damage of the 2008 war with Russia, bilateral trade between China and Georgia has seen a steady growth, especially since 2010 (Larsen, 2017b, p. 5). Since then, China has turned into one of Georgia's top trading partners and is currently at number three by trade turnover - based on the available 2019 data, falling behind Turkey and Russia and ahead of Azerbaijan, US, Armenia and Ukraine.

Georgian exports to China stood at just $\$ 6$ million in 2009 as opposed to $\$ 223$ million in 2019. At the same time, Chinese imports to Georgia increased from $\$ 175$ million in 2009 to $\$ 858$ million in 2019. The overall trade turnover between the two countries increased from less than $\$ 4$ million in 1992 to $\$ 1,081$ million in 2019 amounting to over $8 \%$ of Georgia's overall trade turnover (External Trade of Georgia 2019. Statistical Publication, p. 13-15; Larsen, 2017b, p. 5). In 2019, the top exports of Georgia to China were minerals (copper ore, concentrates), beverages (wine and other spirits), and technical/medical equipment (Georgia Exports 
to China; see also: Larsen, 2017b, p. 5; Georgia, The Observatory of Economic Complexity). In 2018 alone Georgia exported 6.95 million bottles of wine to China, making the latter Georgia's top three wine exporting countries after Russia and Ukraine (China Ranks 3rd for Georgia's Wine Exports in 2018).

Chinese companies have established a strong presence in various sectors in Georgia too from finance and telecommunications to tourism, mining, real estate, and road construction (Larsen, 2017b, p. 8; Muller, 2018; Lomsadze, 2019b; Georgia PM Inspects POWERCHINA's Expressway Project). In other words, "China has ... become an important source of FDI for Georgia" (Larsen, $2017 \mathrm{~b}$, p. 7) although according to the second quarter of 2020 estimates, it does not feature among the top ten direct investor countries in Georgia (Foreign Direct Investments by Countries).

\section{China, Georgia and the Belt and Road Initiative Belt and Road: Background}

China's BRI was first announced in 2013 by China's then new President Xi Jinping ${ }^{1}$ on his visit to Kazakhstan. Since then much has been said and written about this initiative, sometimes also dubbed as "the project of the century" (Larsen, 2017b, p. 12). Still, there are more questions and uncertainties surrounding it than answers and some have rightly pointed out the scarcity of the "[v]erified information regarding the BRI and related projects" (Belt and Road Initiative). "Which projects are actually BRI projects? How much has been invested along the route so far? What are the implications of BRI projects for local and regional economies, societies and the environment? What are the specific financial risks of BRI projects? How far does the Belt and Road Initiative reshape the global trade system and potentially the geopolitical order?" (Belt and Road Initiative). These are some of the questions that have come up many

1 President of the People's Republic of China since March 2013 and the General Secretary of the Communist Party of China since November 2012. 
times before but have been difficult to answer satisfactorily (Belt and Road Initiative). The goal of this paper is not to provide definitive answers to all these questions but to discuss some of them further in the context of Georgia more specifically.

In 2017 the Asian Development Bank (ADB) estimated that it would "need to invest $\$ 26$ trillion over the 15-years from 2016 to 2030 , or $\$ 1.7$ trillion per year" in order to meet the infrastructure needs of the ADB's 45 developing member countries (DMCs) (Meeting Asia's Infrastructure Needs, vii). To address these needs, several "regional and sub-regional initiatives" have been proposed to improve transport links between countries in Asia. One of those initiatives is the BRI, one of the most ambitious initiatives of its kind - "a transcontinental long-term policy and investment program which aims at infrastructure development and acceleration of the economic integration of countries along the route of the historic Silk Road" (Belt and Road Initiative). As many have noted, announcement of this "global initiative" was also an announcement of China's ambitions of becoming a global player (author's interviews, July-Aug. 2020). According to the official outline of the BRI, issued by China in 2015, the aim of the BRI is to "promote the connectivity of Asian, European and African continents and their adjacent seas, establish and strengthen partnerships among the countries along the Belt and Road, set up all-dimensional, multi-tiered and composite connectivity networks, and realize diversified, independent, balanced and sustainable development in these countries" (Belt and Road Initiative). Currently, China's official Belt and Road Portal lists profiles of 143 "countries along the Belt and Road" as well as others with whom China had signed cooperation agreements on the BRI (International Cooperation: Profiles).

The BRI is comprised of two land-based and sea-based initiatives: 1) The Silk Road Economic Belt (SREB) is a land-based initiative and in itself is comprised of six different development "corridors" across 
Eurasia ${ }^{1}$; 2) The $21^{\text {st }}$ Century Maritime Silk Road, on the other hand, is a sea-based initiative (Belt and Road Initiative). Various stateowned and other banks and funds ${ }^{2}$ as well as international financial institutions $\mathrm{s}^{3}$ and private investors from China and around the world have been involved in funding different BRI-related projects (Belt and Road Initiative; Larsen, 2017b, p. 14). The total funding needed for the BRI is estimated to be between 4 and 8 trillion USD (Belt and Road Initiative).

\section{Georgia's Involvement in the Belt and Road Georgia as a "land-bridge"}

Georgia's involvement in the BRI comes within the China-Central Asia-West Asia Economic Corridor (CCWAEC) within the SREB, which stretches from China to Turkey and the Black Sea. With its strategic geographic location Georgia can offer both land (railway links) and sea (maritime) transport routes to the CCWAEC (Larsen, 2017b, p. 14).

While "[t]he overwhelming majority of trade between the EU and China" still goes through the sea, it has been suggested that new rail links between the two continents could potentially change these established, traditional "trade patterns" and could pose a "challeng[e] [to] airlines and shipping companies" (Jensen \& Vana). Transport of goods by sea is cheaper than by rail, but it also takes much longer. Depending on a destination, for a shipment from China to reach Europe (via South China Sea, the Malacca Strait, the Indian Ocean, and the Suez Canal) it may take anywhere from 30 to

1 1) New Eurasian Land Bridge Economic Corridor (NELBEC); 2) ChinaMongolia-Russia Economic Corridor (CMREC); 3) China-Central Asia-West Asia Economic Corridor (CCWAEC); 4) China-Indochina Peninsula Economic Corridor (CICPEC); 5) Bangladesh-China-India-Myanmar Economic Corridor (BCIMEC); and 6) China-Pakistan Economic Corridor (CPEC).

2 Silk Road Fund alone, set up by China, has $\$ 40$ billion reserves "aimed at promoting private investment along [the BRI]" (Duchâtel et al., 2016).

3 Such as the ADB, the Beijing-based AIIB and the Shanghai-based New Development Bank (NDB) (Belt and Road Initiative). 
48 days (How Long Does the Ship from China Sail?). "A container ship too large for the Suez Canal has to make a $24,000 \mathrm{~km}$ journey to reach Europe" while it takes "approximately 11,000km to reach the same destination [by train]" (Jensen \& Vana). Also, while not as environmentally friendly form of transportation as sea travel, "rail cargo ... emits less carbon dioxide (CO2) than air travel" (Josephs, 2017).

With the Baku-Tbilisi-Kars (BTK) railway, Georgia is part of the overland transport corridor that links Asia and Europe, and via the Yavuz Sultan Selim Bridge over the Bosphorus in Istanbul, Turkey, which officially opened in 2016, Georgia also has "an uninterrupted rail link to Europe" (Larsen, 2017b, p. 15).

Although it pre-dates the BRI and was first signed in Tbilisi in 2007, the BTK has a potential to play a key role in the BRI (BakuTbilisi-Kars (BTK) Railway Track Becomes Operational to Carry Chinese Goods to Europe). It is "a flagship project" of the TransCaspian East-West Trade and Transit Corridor, sometimes also referred to as the "Middle Corridor" - the 6,500-kilometer corridor that links Southeast Asia and China to Europe by passing through Kazakhstan, the Caspian Sea, Azerbaijan and Georgia from where one route branches out to Turkey (going through the Marmaray Tunnel under the Bosporus Strait) and the other one to Ukraine (and then Poland) and Romania via the Black Sea (Calabrese, 2019; see also: B\&R countries convene on Trans-Caspian corridor construction) $)^{1}$.

In order to develop this Trans-Caspian corridorfurther,Azerbaijan, Georgia and Kazakhstan established the International Association Trans-Caspian International Transport Route (TITR) in 2013 "with the participation of railway and Maritime administrations" from these three countries (TITR; see also: Kenderdine, 2018; Uatkhanov, 2017). Since then, Turkey and Ukraine also joined the

1 For more on this, see also: Past Events: The 'Trans-Caspian East-West Trade \& Transit Corridor' Forum”, 26-27 June 2017; Putz, 2016. 
TITR as regular member states ${ }^{1}$ alongside with several associate members and partners, including China's Lianyungang Port (Middle Corridor).

In order to attract more cargo from China, Georgian officials seem determined "to ensure smooth transportation along the Black Sea ... [and] ... better access to European markets". As a result, Georgia "is working to establish direct feeder services with Romania and Ukraine and to increase frequency of ferry transportation with Bulgaria" (author's communication with the Embassy of Georgia in Beijing ${ }^{2}, 22$ Oct. 2020). As a representative of Georgia's Embassy in Beijing noted, "direct and improved connections on the Black Sea will sustain the extension of the Middle Corridor to the Rhine Danube Corridor (Bulgaria, Czech Republic, Germany, France, Hungary, Austria, Romania, and Slovakia) and North Sea - Baltic Corridor (The Netherlands, Belgium, Germany, Poland, Lithuania, Latvia, Estonia, Finland)" (author's communication, 22 Oct. 2020).

At the official inauguration ceremony of the BTK in October 2017, Azerbaijan's President Ilham Aliyev further noted that the 826-kilometer rail line of the BTK was the "shortest and most reliable link between Asia and Europe" (Baku-Tbilisi-Kars Railway Line Officially Launched by Radio Free Europe) $)^{3}$. The first transit train, which arrived from China to Georgia in December 2015 - "marking the opening of the "Silk Railroad"" - only took 15 days (Georgia

${ }^{1}$ Currently TITR has eight regular members - three from Azerbaijan, two from Kazakhstan, and one from Georgia, Turkey and Ukraine each. For more on this, see: Members of the Association are commercial and non-commercial organizations, which are interested in cooperation with the Association and in contributing to the development of its activity. For more on TITR ("Middle Corridor") see also: Leijen (2019); Miholjcic (2018).

2 Unless otherwise noted, all mention of the Embassy of Georgia to Beijing refers to the author's communication with them.

3 Out of 826-kilometre rail-line, 504 kilometres are running through the territory of Azerbaijan, $263 \mathrm{~km}$ through Georgia and $79 \mathrm{~km}$ through Turkey (Development Issues of Trans-Caspian Int'l Transport Route Discussed in Baku). 
Welcomes 'Silk Railway' Cargo Train from China to Turkey)'. This rail journey from eastern China to Istanbul was estimated to be about 25 days shorter than a similar journey by the sea route, highlighting the significance of the BTK railway (Topuria, 2016). More recently, it was reported that in June 2020 "a new record was set by a freight train traveling from China to Turkey" through the "Middle Corridor". From Xi' an - central China to Izmit, Turkey the train took only 12 days after crossing the China-Kazakhstan border (New Records Set on the Middle Corridor to Turkey).

For China, this route could be "a strategic option" to diversify its transport corridors. The BTK, and the Trans-Caspian route in general, can act as an alternative route to China's "Northern Corridor" that goes through Russia - The New Eurasian Land Bridge Economic Corridor (NELBEC) and the China-Mongolia-Russia Economic Corridor (CMREC). In this way, China can lessen its dependence on Russia as a transit route and Georgia is determined to play a key role in this, acting as a "hub connecting Europe and Asia" (Opening of the 26th China Lanzhou Investment and Trade Fair; see also: Van Dijk \& Martens, 2016, p. 3). ${ }^{2}$

In 2018, Georgian Railway LLC - the national railway company of Georgia, signed a further agreement with Germany's Deutsche Bahn - "the largest rail freight provider in Europe". The aim of this agreement was to develop new cargo routes across Europe and Asia and improve existing ones (Deutsche Bahn and Georgian Railway Sign Agreement Strengthening European-Asian Rail Freight). In particular, this collaboration is meant "to provide transport services

1 The rail cargo originated in South Korea from where it was first shipped to China's eastern port of Lianyungang and then went through Kazakhstan, (ferried via) Caspian Sea, Azerbaijan, and Georgia on rail and from then on was to be shipped to Istanbul, Turkey (Georgia Welcomes ‘Silk Railway' Cargo Train from China to Turkey).

${ }^{2}$ For more on the BTK, see: China Connects Rail to Europe without Russia as BTK Route Runs South via Caucasus and Turkey; Uysal (2014).

${ }^{3}$ A memorandum of understanding (MoU) was signed already in July 2016 (DB and Georgian Railways Agree Cooperation). 
in two directions: the trans-Caspian movement of goods between China and Europe as well as a second corridor providing for the movement of goods to and from Europe to Iran and Iraq via Georgia" (Daly, 2016). More recently, as Davit Saganelidze, the CEO of the JSC Partnership Fund" of Georgia stated, "the opening of a railway transportation corridor connecting Eurasia via Georgia is one of the most promising plans that can achieve an increase in inter-regional rail transportation. Georgia actively participates in the construction of the 'Belt and Road', becoming a bridge between the European and Asian markets, and an important gateway connecting Europe and China, with huge potential" (cited in: Opening of the 26th China Lanzhou Investment and Trade Fair) ${ }^{2}$.

The rail connection between China and Europe has acquired an even greater importance during the current global pandemic (Xinhua Headlines: Railway Freight Express Puts China-EU Cooperation Amid Pandemic on Fast Track). According to Chinese media outlets, rail links between the two continents have played a significant role in the fight against Covid-19, acting as "green passages" for transporting supplies and raw materials from China to Europe. The restoration of regular rail operations between China and Europe also provides "an impetus" to economic recovery of both continents "by stabilising trade and supply chains" amidst the pandemic (Xinhua Headlines: Railway Freight Express Puts China-EU Cooperation Amid Pandemic on Fast Track).

\footnotetext{
1 A state-owned investment fund in Georgia, established in 2011 with the aim to "invest[] in commercially viable projects" (JSC Partnership Fund. Invest in Georgia). Its assets are valued at 4.9 billion Georgian Lari (GEL), with equity at 2.3 billion GEL. It owns 100\% of shares in Georgian Railway, Georgian Oil \& Gas Corporation, Georgian State Electricity System, Electricity System Commercial Operator, and $24.5 \%$ of shares in Telasi (JSC Partnership Fund. LinkedIn). For more on this, see also: Partnership Fund.

2 Saganelidze was speaking at the online opening ceremony of the $26^{\text {th }}$ China Lanzhou Investment and Trade Fair and the Silk Road Cooperation and Development High-end Forum in Lanzhou, Gansu, where Georgia and Hungary were invited guests of honour (Opening of the 26th China Lanzhou Investment and Trade Fair).
} 
However, for most of the China-Europe freight train routes, the "Northern Corridor" remains a preferred option (passing through China, Kazakhstan, Russia, Belarus, and Poland) (Mardell, 2019). One of the reasons for that could be the cost-efficiency of this route. Trains through the Trans-Caspian "Middle Corridor" currently take longer - on average 14-18 days. In comparison, the "Chengdu-Europe Express Rail" from China to Germany, for instance, takes on average 12-14 days (Silk Road ChengduEurope Express Rail-Connecting the World). There is hope that this timeframe can be reduced even further and that in the future, it will be possible "to connect China and Europe in 10 days" (Xinhua Headlines: Railway Freight Express Puts China-EU Cooperation Amid Pandemic on Fast Track). This raises the issue of competitiveness of the Trans-Caspian route which will be discussed further below.

\section{Georgia as a "maritime outlet"}

As many have note before, in addition to acting as a "landbridge", Georgia also has a potential to "serve as a maritime outlet to Europe" thanks to its Black Sea ports of Batumi, Poti, and Anaklia (Larsen, 2017b, p. 15). This route gives China not only access to these Black Sea ports but also to Supsa and Kulevi - Georgia's "two oil export terminals", which carry oil from Azerbaijan, Kazakhstan, and Turkmenistan (Daly, 2016).

Black Sea Deep Water Port Project in Anaklia, a small seaside town in western Georgia, close to breakaway Abkhazia, deserves a particular mention here. At 17 meters, Anaklia port is supposed to be the "first-ever deep-water port" in Georgia ${ }^{1}$ with an estimated $\$ 2.5$ billion investment in the project (Larsen, 2017b, p. 15; see also: TBC Holding, Conti Joint Venture Awarded Anaklia Deep-Sea

${ }^{1}$ The depth of the harbours in Georgia's two other port cities - Poti and Batumi are up to 8 and 14 meters respectively (Anaklia Port - Georgia's Key to the New "Silk Road" of the 21st Century). 
Port Project) ${ }^{1}$. Its geographic location - depth of its waters as well as "relative proximity to European markets - make it uniquely suited to serve large vessels" (Larsen, 2017c). Once completed, it "is expected to become one of the largest ports in the Black Sea region with a handling capacity of up to 10,000 TEU [Twenty-foot Equivalent Unit] vessels" (Anaklia Deep Sea Port Marine Works Awarded to Van Oord $)^{2}$. According to Levan Akhvlediani - the CEO of Anaklia Development Consortium (ADC) at the time, the port was expected "to eventually capture 60 percent of the Georgian container market" (cited in Larsen, 2017c). In the first phase of the operation, it would be able to handle 900,000 TEU annually - 50 percent more than Poti's current 600,000 TEU capacity (Larsen, 2017c). According to the reports in the Georgian media, by the end of the final phase, the port "must be able to handle 100 million tonnes of cargo per year" (Construction of Anaklia Deep Sea Port Kicks Off). ${ }^{3}$

At the time of its inception in $2014,{ }^{4}$ there was a lot of excitement about this project and many in Georgia viewed it "with hope and expectation" (Rukhadze, 2015). It was lauded as "the project of the century" (Giorgi Kvirikashvili 5 cited in: Project of the Century' Anaklia Deep Sea Port will be Built by 2020) and

1 The project was initiated by the Georgian government with $\$ 100$ million investment pledge (Republic of Georgia Selects Anaklia Development Consortium to Build a Deep Sea Port in Anaklia).

2 Poti - Georgia's largest port at present - currently handles 1,500 TEU ships (Larsen, 2017c).

${ }^{3}$ As one analyst noted, to put it in perspective, "the largest existing port on the Black Sea, Novorossiysk (Russian Federation), handles 70 million tons per year" (Menabde, 2015).

${ }^{4}$ The idea of building a port in Anaklia is not new but more recently, it dates to Mikheil Saakashvili's Presidency (in office 2004-2013) (Georgian Gov't Cancels Anaklia Development Consortium Contract for Construction of Deep Sea Port on Black Sea Coast). At the time, alongside the port in Anaklia, Saakashvili also planned to build a new city - Lazika (referring to the ancient kingdom in western Georgia) (Rukhadze, 2015).

5 Prime Minister of Georgia (2015-18). 
"a one-of-a-kind investment" (Mamuka Khazaradze ${ }^{1}$ cited in: Republic of Georgia Selects Anaklia Development Consortium to Build a Deep Sea Port in Anaklia) that would be "creating a new, faster maritime corridor between China and Europe, helping to restore the historic Silk Road" (Construction of Anaklia Deep Sea Port Kicks Off). The port was also supposed to "restore Georgia to its rightful place ... as a logistics hub" and become "part of the fabric of "One Belt, One Road" (Levan Akhvlediani cited in: Larsen, 2017c). However, as Joseph Larsen points out, "the project that may have the most importance for China's economic interests [in Georgia] doesn't involve a single Chinese investor" (Larsen, 2017c).

Instead, it was the ADC - "A joint venture between Georgian TBC Holding and U.S.-based Conti International" that won the tender (TBC Holding, Conti Joint Venture Awarded Anaklia Deep-Sea Port Project $)^{2}$. According to the official statement, "ADC's vision for the Anaklia Port is to create a world class port complex for Georgia and establish Anaklia as a focal point of trade to and from Central Asia and on the New Silk Road trade route between China and Europe" (About Us). The port complex was also supposed to incorporate

1 Khazaradze is one of the founders and former Chairman of the ADC and founder and former Chairman of the TBC Bank JSC - one of the largest banks in Georgia (Republic of Georgia Selects Anaklia Development Consortium to Build a Deep Sea Port in Anaklia).

2 The Consortium is comprised of "TBC Holding from Georgia, SSA Marine from the United States, British Wondernet Express working in Central Asia, and G-Star Ltd. From Bulgaria”. For more on this see: ANAKLIA PHASE 1. Initially though, the founding partners of the ADC were TBC Holding and Conti Group International, a New Jersey-based construction and development company. They were "awarded the contract to build and operate deep-sea port" in 2016 with an expected date of completion at the end of 2020 (TBC Holding, Conti Joint Venture Awarded Anaklia Deep-Sea Port Project). Construction works started in 2017 but in 2019, Conti Group, who holds $42 \%$ of the shares, declared its intention to exit the Consortium (Conti Group Reported to be Exiting Anaklia Port Project; see also: US-Based Conti Group 'Confirms Intention to Exit' Anaklia Development Consortium; US-Based Conti Group Not to Leave Anaklia Development Consortium). 
"a 600-hectare Free Industrial Zone (FIZ) .... allowing businesses to produce goods for export under a tax-free regime". In addition, the plan was to turn Anaklia into a regional "financial and banking centre" (Larsen, 2017c). However, in January 2020, after months of speculation, Georgian government cancelled ADC's contract citing failure of the consortium to bring in new investments (Georgian Gov't Cancels Anaklia Development Consortium Contract for Construction of Deep Sea Port on Black Sea Coast).

As Larsen (2017b, p. 15) notes, examples from Georgia highlight one of the underpinning concepts of the CCWAEC and the BRI in general: it builds upon the existing infrastructure initiatives and tries to complement it rather than replace it. Transport Corridor Europe-Caucasus-Asia (TRACECA) ${ }^{1}$ and TITR are some of these examples. Georgia is also in a good position "to maximize its potential as the fulcrum of two nascent regional groupings, the Georgia, Ukraine, Azerbaijan, and Moldova (GUAM) group and the Azerbaijan, Georgia, Turkey trilateral group (AGT)" (Larsen, 2017b, p. 15) ${ }^{2}$. Within GUAM, for instance, "Georgia is uniquely positioned to link China to Ukraine and Moldova via its Black Sea ports" (Larsen, 2017b, p. 15). This is becoming more and more relevant, given China's growing interest and links

${ }^{1}$ Founded in 1998 by Azerbaijan, Armenia, Georgia, Kazakhstan, Kyrgyzstan, Moldova, Romania, Tajikistan, Turkey, Ukraine and Uzbekistan, TRACECA is an international initiative "promoting the development of regional transport dialogue and ensuring the efficient and reliable Euro-Asian transport links". Iran joined the programme in 2009 as the $13^{\text {th }}$ member country (TITR).

2 Organisation for Democracy and Economic Development (GUAM) is a regional organisation formed in 1997 by Azerbaijan, Georgia, Moldova, and Ukraine. Uzbekistan joined in 1999 but withdrew in 2005. For more on GUAM, see: https://guam-organization.org/en/. All four countries of the GUAM are also participating in the BRI (Larsen, 2017b, p. 16).

3 The Azerbaijan, Georgia and Turkey (AGT) trilateral cooperation was officially established in 2012 by the Trabzon Declaration. Its aim is to enhance existing partnerships between these countries by "strengthening political dialogue and promoting mutually relevant projects" (Frappi \& Valigi, 2015, p. 2; see also: Cecire, 2013). 
with these two countries (Larsen, 2017b, p. 15; see also: Johnson, 2020; Zhen, 2017). ${ }^{1}$

In this way, Georgia has a potential to play an important role "as a hub in two directions - from China to Turkey and Ukraine to China, and vice-versa" (Topuria, 2016). Moreover, it provides a way to avoid overdependence on Russia as a transit route not only for China but also for Turkey and Ukraine, both of whom have had rather tense relations with Moscow over the past few years (Topuria, 2016).

\section{China's Presence in Georgia: Much ado About Nothing? What Does China Want in Georgia?}

So, what does the above discussion tell us about China-Georgia relations? What does Chinese presence and activities mean for Georgia and China, and the wider region?

When asked about China's growing interest in the Caucasus, representative of Georgia's Embassy in Beijing highlighted the many examples of China's increased involvement in Georgia and beyond but was also quick to point out that "despite this, any talk about China's long-term geo-political or geo-economic interests and greater Chinese presence in the region were, at this point, premature and exaggerated". Many would agree that any talk about China's emerging political strategy in Georgia is also an exaggeration and that there is no doubt "China continues to take into account Russia's policy towards South Caucasus and still considers this region as Moscow's traditional sphere of interest". In this way, "it is trade-economic related issues that dominate the agenda in Beijing's relations with Georgia and at this point China has not

${ }^{1}$ Ukraine, in particular, has seen a significant growth of bilateral trade with China. In 2015, it formally joined the BRI sending a cargo to China via the TITR (Ukraine Expects New Infrastructure Projects from Belt and Road Forum: Deputy Minister). Trade turnover between the two countries reached $\$ 12.79$ billion in 2019: "Ukrainian exports to China grew by 63.3 percent year on year to reach 3.59 billion dollars, while imports increased by 20.9 percent to hit 9.2 billion dollars" (Ukraine, China to Deepen Ties: Ukrainian Deputy PM). 
expressed any long-term geopolitical interests [towards Georgia]" (communication with Embassy of Georgia in Beijing, 26 Aug. 2020).

Similarly, when it comes to security dimension of the BRI, Georgia does not participate in any format with China in this direction. It has no ties with China-led Shanghai Cooperation Organisation $(\mathrm{SCO})^{1}$ and has no plans to do so in the future (communication with Embassy of Georgia in Beijing, 26 Aug. 2020). Georgian side has continuously emphasised that its eagerness to develop closer ties with China "does not mean that Georgia is changing its Euro-Atlantic path" and that the country is still aspiring towards membership of the NATO and the EU (Topuria, 2016, emphasis original). In other words, "Georgia's main interest in China's BRI relates to economic issues and realisation of specific investment projects. There is no political agenda in this regard" (communication with Embassy of Georgia in Beijing, 26 Aug. 2020).

As mentioned above, as a transit route for rail cargo from China to Europe, within the remits of the BRI, Georgia has successful cooperation with Chinese cities of Lianyungang and $\mathrm{Xi}$ 'an in particular. Nevertheless, "these rail routes mainly operate in a pilot, test regime". Thus, at the present time, "the aim of the Georgian side is to make Trans-Caspian route operate on a regular basis and with full capacity and turn it into a real additional route for transportation of cargo from China to Europe. This of course will be impossible without the support of the People's Republic of China" (communication with Embassy of Georgia in Beijing, 26 Aug. 2020).

Popularisation of this "Middle Corridor" indeed seems to be a rather sensitive issue for the Georgian side and was pointed out as one of the important issues on the "Georgia-China political and economic agenda" which has been left open for now. "Despite the readiness and willingness of the Georgian side, the TITR-Middle Corridor is still absent from the official BRI maps" and at present,

The SCO is a multilateral security organisation formed in 2001 by China, Kazakhstan, Kyrgyzstan, Russia, Tajikistan and Uzbekistan. 
most of the cargo from China to Europe still passes through Russia, bypassing Georgia (communication with Embassy of Georgia in Beijing, 26 Aug. 2020). From Georgian perspective, for the country to play a more active role in the BRI, it is important for the BTK to form a stable, integral part of the initiative and for this to happen, China needs "to support the development of this Trans-Caspian transport corridor on Georgia's territory ... and include Trans-Caspian corridor on the official transit routes of the BRI" (communication with Embassy of Georgia in Beijing, 26 Aug. 2020).

In recent years others have also pointed to China's notable absence on the "Middle Corridor". As Jacob Mardell (2019) points out, while the "Middle Corridor" is often associated with the CCWAEC - one of the six official land corridors of the BRI, its remit remains "vague" and the official route of the CCWAEC, in fact, goes through Iran rather than South Caucasus. Thus, "despite frequent talk of synergy between 'Turkey's Middle Corridor' and the BRI, cooperation is limited to the signing of MoUs". Similarly, the BTK is also often associated with the BRI and the Georgian and Azerbaijani authorities are keen to point out its importance "to the New Silk Road", but Beijing's role in its infrastructure development has largely been "absent" or at best "minimal".

One way to explain China's hesitance in this regard is Beijing's continued scepticism of the viability of the "Middle Corridor". As Mardell argues, "it may be the shortest route between Europe and China, but the middle corridor involves crossing five borders and transiting one or two seas, depending on where the cargo's heading" (Mardell, 2019). This means dealing with several different languages, cultures, and legal systems, which makes navigating customs procedures even more difficult. As a result, it is difficult for the "Middle Corridor" to "compete with the "main overland route through Russia", which remains an easier, and cheaper way to transport goods between China and Europe (Mardell, 2019). 
As already mentioned above, the key here is Beijing's interest in diversifying its transport routes. In the words of Russia's President Vladimir Putin, at present China and Russia enjoy "an unprecedented level" of bilateral partnership and cooperation". The two leaders - President Putin and China's Xi Jinping - "have met nearly 30 times" since Xi assumed power in 2013 and the latter has previously described Putin as his "best friend and colleague" (As Relations With U.S. Sour, Xi Describes Putin As 'Best Friend' At Moscow Meeting). However, as Revaz Topuria points out, "here an important issue at play is the issue of trust. How much these two countries China and Russia - actually trust each other" (author's interview, 16 July 2020). Many have cast doubt over how long this seemingly good relationship between these two powerful and ambitious leaders might last (see: Putin and Xi: Not Quite the Allies They Seem). "I think this is temporary", argues Topuria, "until one of them becomes strong enough to show the other its real power and influence. .... So, there are several reasons why China does not want to be dependent solely on Russia" (author's interview, 16 July 2020). According to another Georgian analyst, China is also concerned about Moscow's strained relations with its neighbours, especially Ukraine, but also its occasional disputes with Belarus and the Baltic states. "Apart from that, an alternative railway route would become an important bargaining chip for China in its tariff negotiations with Russian Railways" (David Avalishvili cited in: Menabde, 2016). Similarly, Moscow is also suspicious of China and sees growing Chinese influence in Russia, especially in its Far East, as a threat. As one government official in Georgia noted, "in one way they have a perfect relationship but if you zoom-in, long-term, China can be a problem for Russia. China can 'swallow' Russia together with its far East" (author's interview, 5 July 2020).

1 In the past few years alone, the two countries have signed agreements worth billions in US dollars, such as the $\$ 400$ billion gas supply deal between Russia and China signed in 2014, for instance (Anishchuk, 2014). 
Thus, the main appeal of the "Middle Corridor" for China "is that it bypasses Russia". However, while "Beijing likes to build redundancies into global trade networks" and probably views the "Middle Corridor" as "an insurance policy .... should problems arise along the Northern Corridor", this project does not seem to be at the top of its current "list of priorities" (Mardell, 2019). So, despite strong Chinese interest and support at the rhetorical level, some suspect that Beijing might be "playing something of a waiting game". Thus, at present, as Mardell notes, "the Middle Corridor remains a firmly regional initiative" and "faces serious obstacles to becoming an alternative China-EU route" (Mardell, 2019).

\section{Anaklia: A Geopolitical Conundrum?}

The future prospects of this route were further questioned last year when the termination of the ADC's contract was announced, putting the construction of the Black Sea Deep Water Port in Anaklia under threat (Georgian Gov't Cancels Anaklia Development Consortium Contract for Construction of Deep Sea Port on Black Sea Coast). However, this time, the decision was down to the Georgian government rather than reluctance from the Chinese counterparts.

From the very start, Anaklia project has been marred with controversy and has turned into a geopolitical conundrum involving the China, US, Russia triangle. When the Georgian government first announced its plans to build port in Anaklia, it opened doors to both Georgian and international investors. 12 companies participated in the tender, and from seven longlisted ones, two were shortlisted in June 2015: the above-mentioned ADC and Power China-Hubei Hongyuan Power Engineering Company, Ltd. (Chinese Power Company Front-Runner in Anaklia Port Project). The latter - "one of the largest Chinese state companies", had an estimated wealth of $\$ 70.4$ billion in 2015 and was employing some 200,000 people worldwide. It was widely considered to be the front-runner and was tipped to be the favourite to win the tender (Menabde, 2015). At the 
time Georgia's Prime Minister Garibashvili even held high profile meetings with the company officials (Chinese Power Company Front-Runner in Anaklia Port Project).

Indeed, for many, having a Chinese government backed company take charge of the construction of this project seemed like an obvious choice. As one analyst explained, "China was considered the preferred partner because the construction of the port in Anaklia would explicitly be part of Beijing's new 'Silk Road' trans-Eurasian transit development policy" (Menabde, 2016). Others believed that "only a power as strong as China" would be able to protect the project from any Russian interference. After all, Russian military, stationed in Abkhazia, are within several kilometers away from Anaklia, and were always deemed a threat to the completion of the project. China's involvement might have somewhat deterred Russians. As journalist Zurab Gogoberidze noted, "Moscow still takes China's position into consideration, when it attempts foreign policy gambles" (cited in: Menabde, 2015). Thus, it came as a huge surprise to many when in 2016, "[a]fter a long period of negotiations", it was the ADC that was announced as the winner of the tender, not Power China (Menabde, 2016).

At the time, some were already predicting that "without Beijing's direct involvement" it would be difficult to complete the Anaklia project. As one Georgian economist noted, "[t]he transportation infrastructure in Georgia, Azerbaijan, the Caspian Sea and in Kazakhstan will not be able to carry 100 million tons of goods per year. For example, Georgian railways cannot service such throughput. These problems could have been solved only with significant interest from and active participation of the Chinese state. Yet the Georgian government made another decision" (Giorgi Khukhashvili cited in: Menabde, 2016). At this point we can only speculate whether China's enthusiasm, and engagement with the "Middle Corridor" might have been different had it been granted access to the Anaklia project. 
Similarly, while it is hard to confirm this information, many have long suspected some kind of US involvement in the Georgian government's decision to reject the Chinese bid in favour of a consortium with an American partner - Conti Group International. "In general, the fact that the US is not thrilled about the BRI is well known", notes Revaz Topuria, "but the US cannot go against us signing free trade agreements [and developing economic ties] with other, big countries and think that this is a bad thing because this is clearly a good thing" (author's interview, 16 July 2020). But Georgia of course remains conscious of the considerations of its most valuable strategic partner - The United States. As one Georgian official noted, Americans consider China as the main strategic opponent nowadays and they also confirm this rather openly. For them, "Russia is a tactical problem, but China is a geopolitical and strategic (geo-strategic) problem. ... So, whether we want or not we have to take this into consideration. It might be that it actually is indeed beneficial for Georgia to attract Chinese investment and actually it might even be that it does not even pose that much threat but you just have to take into account the interests of your strategic partners" (author's interview, 5 July 2020).

While the Chinese companies might have missed out in participating in the construction of the Anaklia port, it seems both in the Chinese and American interests to successfully see this project through. With China, the benefits of having another sea route available via Georgia have already been outlined above, but with the US, one of the main interests in this project might be security related and linked "to the existing disbalance with Russia" (Glurjidze \& Dzamukashvili, 2020). In recent years, NATO and Georgia have been conducting some military exercises in Poti. However, currently, Poti port does not have "adequate capacity to accommodate large vessels". In this way, as some point out, "the much larger Anaklia deep-sea port" could play "a pivotal role ... for the development of these military activities, further enhancing the country's strategic 
significance for NATO” (Glurjidze \& Dzamukashvili, 2020; see also: Menabde, 2019a; Daly, 2020). The US has also been vocal in support of this project. As the US Secretary of State stated in June 2019, "[t]hese and other projects will strengthen Georgia's relations with countries with market economies and avoid the danger of becoming a victim of the economic influence of Russia and China. These imaginary friends do not care about the interests of Georgia" (Georgian Gov't Cancels Anaklia Development Consortium Contract for Construction of Deep Sea Port on Black Sea Coast).

So why did Georgia suddenly put breaks on the project which could potentially have such important economic and security implications for the country? Some have argued that it has to do with "economic corruption" and the in-fight among different political groupings and business interests in Georgia (Daly, 2020; see also: Menabde, 2019b). Former Prime Minister Bidzina Ivanishvili, ${ }^{1}$ who many have dubbed as the "informal"/ "de facto ruler" of the country, has been engulfed in a bitter personal rivalry with Mamuka Khazaradze - founder of the $\mathrm{ADC}$, and this has been reflected on the developments surrounding the Anaklia project too. This affair, labelled as the "millionaire vs billionaire" of the Georgian politics, has gripped the country after charges of money laundering of $\$ 17$ million were brought against Khazaradze and his Deputy in 2019 (Lomsadze, 2019a). Many have labelled the charges as manufactured and "politically motivated" (Zalinger, 2020). Since then, Khazaradze has even founded a political party - Lelo for Georgia, and plans to challenge Ivanishvili's ruling party (Georgian Gov't Cancels Anaklia Development Consortium Contract for Construction of Deep Sea Port on Black Sea Coast).

However, others have claimed that developments in Anaklia also might have something to do with the Georgian government trying to

${ }^{1}$ In office in 2012-13. Billionaire Ivanishvili is Georgia's richest man. $\mathrm{He}$ is a prominent businessman and philanthropist who founded the current ruling party of Georgia - the Georgian Dream-Democratic Georgia party in 2012 (Ex-PM Ivanishvili to Chair Georgian Dream Party). He served as the chairman of the party in 2018-21. 
appease the Kremlin. In fact, some have even called Russia "[t]he main foreign enemy of the Anaklia project" (Georgian Gov't Cancels Anaklia Development Consortium Contract for Construction of Deep Sea Port on Black Sea Coast). Indeed, Moscow has never shied away from stating "that it does not like the idea of the construction of a port in Anaklia" and that it "is not in its interests" (Georgian Gov't Cancels Anaklia Development Consortium Contract for Construction of Deep Sea Port on Black Sea Coast; see also: Menabde, 2019b, Daly, 2020). For the Kremlin, any US/NATO-Georgia rapprochement is perceived as a threat and by default, a US-supported project is also viewed as such. If completed, the port in Anaklia could have capacity to host US and NATO "warships" and "US submarines", which Kremlin sees "as a geopolitical threat". Besides, Anaklia's proximity to the Russiabacked Abkhazia poses further threats to Moscow's interests in the region (Georgian Gov't Cancels Anaklia Development Consortium Contract for Construction of Deep Sea Port on Black Sea Coast). Many in Georgia consider that if successful, Anaklia port would bring much needed economic prosperity to the region and could even act as a "pull factor to attract the estranged Abkhazians closer to Georgians and possibly build bridges between the communities" (Rukhadze, 2015).

Moreover, as mentioned above, such a port in Anaklia poses threat to Russia's economic interests too. It will serve as a serious competition to the Russian Black Sea ports for transporting Asian goods to European markets as well as potentially threatening Russian rail cargo transportation routes too (Georgian Gov't Cancels Anaklia Development Consortium Contract for Construction of Deep Sea Port on Black Sea Coast). Thus, many in Georgia's opposition parties have voiced concerns and have accused Ivanishvili and the Georgian government of "complet[ing] the Kremlin's task" by cancelling the ADC's contract (Khazaradze cited in: Georgian Gov't Cancels Anaklia Development Consortium Contract for Construction of Deep Sea Port on Black Sea Coast). Among others, Giorgi Kandelaki, 
a member of the European Georgia Party has argued that " $[t]$ here are only two governments in the world that oppose the Anaklia project. This is the Georgian government - which says one thing, but actually undermines the project, and the second - the Russian government" (Georgian Gov't Cancels Anaklia Development Consortium Contract for Construction of Deep Sea Port on Black Sea Coast) ${ }^{1}$.

It has to be noted that the competition in the region for the best and most viable land or sea routes means that Anaklia project is not in the interests of Georgia's other powerful neighbour Turkey either. The project would undoubtedly compete with other ports in Turkey too and would weaken its standing in the Black Sea (Georgian Gov't Cancels Anaklia Development Consortium Contract for Construction of Deep Sea Port on Black Sea Coast). Currently, Georgia-bound "larger panamax size vessels" are dependent on other ports, mainly Istanbul, where they "are reloaded to feeder ships" before making their way to Poti and Batumi (Govt Selects Two Final Bidders for Anaklia Deep-Sea Port). Thus, the Anaklia project is largely viewed as "a Georgian-American project" and the US is seen as "the largest international lobbyist and supporter of this project" (Georgian Gov't Cancels Anaklia Development Consortium Contract for Construction of Deep Sea Port on Black Sea Coast).

\footnotetext{
1 In fact, this would not be the first time Moscow has attempted "to influence strategically important infrastructure projects in the South Caucasus" (Menabde, 2019a). In 2019, Russia signed a tripartite cooperation memorandum with Azerbaijan and Turkey in Ankara which could potentially significantly transform the BTK railway project (Menabde, 2019a). Given the BTK "was initially meant to facilitate bypassing the Russian Trans-Siberian route" and is viewed as one of its competitor routes, the signing of this memorandum and Georgia's exclusion from it understandably raised concerns in Tbilisi (Garibov, 2019). While Georgia is not opposed to transporting Russian cargo to Turkey through its territory (it already acts as a transit route between Russia and Armenia), it was not happy about "being sidelined in the important decisions regarding the [BTK] project". Moreover, of particular concern to Tbilisi was Moscow's proposal to construct a new gauge rail line from the Georgian border to Kars, Turkey. At present, "the transition from the broad gauge to the standard European gauge $(1,435 \mathrm{~mm})$, which is used in Turkey, is done in Ahalkalaki [Georgia]" and requires a stop at the GeorgianTurkish border (Garibov, 2019).
} 
In September 2020 it was further revealed that the ADC and Bob Meyer - one of the major foreign investors in the project have filed independent arbitration claims against the Georgian government "over their infringed rights in the Anaklia Port project" (Anaklia Development Consortium: Gov't Reneged on Support for Port Project, Wiping out Economic Benefits for Georgia). This is likely to further deter any other new investors from the Anaklia project (Zalinger, 2020). In any case, whether it is Georgia's internal "political squabbling" or the invisible hand of Russia that is threatening to sabotage a project of such strategic importance, many agree that it is damaging Georgia's international reputation and is undermining the country's security (Zalinger, 2020; see also: Will Georgia still build the ambitious Anaklia port? New tender in the works) ${ }^{1}$.

\section{Conclusions}

Many have been sceptical from the very start about the aims and objectives, and the viability of the BRI considering it "unrealistic and over-ambitious" and as some would argue, "over time some of the predictable and also less predictable signs of that have already started showing". In other words, for many analysts, whether in Georgia or abroad, the BRI remains largely "more like a communist propaganda tool" directed mainly at domestic audiences and used to assert China's place globally (author's interview with Revaz Topuria, 16 July 2020). So where does this leave Georgia and its ambitious plans to become a key "regional logistics hub" and play a vital role in the BRI?

As many have pointed out there is "a strong sense of competition between participating states" along the "Middle Corridor" route (Mardell, 2019). Whether it's Georgia or Azerbaijan, officials are quick to point out their respective countries achievements,

1 The Georgian government has recently announced that they will be re-starting the selection process for a new investor for the Anaklia port project in the near future (PM Garibashvili: 'we will start selecting new potential investor for Anaklia Deep Sea Port project in near future'). 
highlight their desirable geographic location and their efforts to build better infrastructure and offer best business environment. However, "the race" to be the best is not necessarily bad and it can work in the advantage of the entire region (Mardell, 2019). Moreover, it is important to keep in mind that while an important player in Asia and the wider world, when it comes to EuropeAsia trade, China is not the only player. As Mardell (2019) notes, "[b]ecause of a persistent global obsession with the BRI, stories about East-West connectivity often choose China as their main protagonist, but there are other markets and producers out there". In other words, "Trans-Caspian traffic can still flow without support from Beijing. ... China is big, and the BRI is important, but there's a lot going on in the Southern Caucasus and Central Asia besides Beijing-sponsored initiatives" (Mardell, 2019). Georgia has a potential to play a significant role in the US trade with the entire Caucasus region and Central Asia too. In 2017, for instance, $61 \%$ of the US-Central Asia trade balance was transited through Georgia (mainly through ports). This accounted to overall 1 billion USD of US exports to Central Asia. Georgia also accounts to an "almost $100 \%$ transit share" of US exports to the Caucasus, equalling 0.8 billion USD in 2017 (Bochorishvili, 2020).

There is no doubt that Georgia should continue its efforts to strengthen economic ties with China but at the same time, it cannot count on China's change of heart, or fortunes, in prioritising the "Middle Corridor" over other routes. Thus, it needs to be on the lookout for other options too in order to maximise its transit/logistics hub potential.

\section{REFERENCES}

About Confucius Institute/Classroom. Confucius Institute/Classroom. http://english.hanban.org/node_10971.htm

About Us. Anaklia Development Consortium. http://anakliadevelopment.com/ about/ 
Aghmosavletis margaliti' didkhans ikashkashebs. Embassy of The People's Republic of China in Georgia on Facebook. 24 July 2020 https://www.facebook.com/111412683679515/posts/180418393445610/?d=n

Anaklia Deep Sea Port Marine Works Awarded to Van Oord. Van Oord Marine Ingenuity. https://www.vanoord.com/news/2018-anaklia-deep-seaport-marine-works-awarded-van-oord

Anaklia Development Consortium: Gov't Reneged on Support for Port Project, Wiping out Economic Benefits for Georgia. Agenda.ge. https://agenda.ge/en/ news/2020/2777

ANAKLIA PHASE 1. Anakliadevelopment.com. http://anakliadevelopment.com/ about/.

Anaklia Port - Georgia's Key to the New "Silk Road" of the 21st Century. Front News International. http://frontnews.eu/news/en/9871/Anaklia-portGeorgias-key-to-the-new-Silk-Road-of-the-21st-century

Anishchuk, A. (2014). As Putin Looks East, China and Russia Sign \$400-Billion Gas Deal. Reuters. https:/uk.reuters.com/article/us-chinarussia-gas/as-putin-looks-east-china-and-russia-sign-400-billion-gas-dealidUSBREA4K07K20140521

As Relations With U.S. Sour, Xi Describes Putin As 'Best Friend' At Moscow Meeting. NPR. https://www.npr.org/2019/06/06/730200317/ as-relations-with-u-s-sour-xi-describes-putin-as-best-friend-at-moscowmeeting?t=1601203129865

Baku-Tbilisi-Kars (BTK) Railway Track Becomes Operational to Carry Chinese Goods to Europe. The Dispatch News Desk. https://dnd.com.pk/btk-railwaytrack-becomes-operational-to-carry-chinese-goods-to-europe/134952

Baku-Tbilisi-Kars Railway Line Officially Launched by Radio Free Europe. Radio Liberty Azerbaijani Service. https:/www.rferl.org/a/baku-tbilisi-kars-railwayline-officially-launched-azerbaijan-georgia-turkey/28824764.html

B\&R countries convene on Trans-Caspian corridor construction. China Daily. http://www.chinadaily.com.cn/a/201802/07/WS5a7add12a3106e7dcc13 b5d4.html

Belt and Road Initiative. https://www.beltroad-initiative.com/

Bochorishvili, K. (2020). Georgia - Gateway to Caucasus and Central Asia Regions - Time to Act. Forbes Georgia. https://forbes.ge/blog/529/Georgiagateway-to-Caucasus-and-central-Asia-regions-Time-to-Act- 
Calabrese, J. (2019). Setting the Middle Corridor on Track. Middle East Institute. https://www.mei.edu/publications/setting-middle-corridor-track

Cecire, M. (2015). China's Growing Presence in Georgia. The Diplomat. https://thediplomat.com/2015/05/chinas-growing-presence-in-georgia/

Cecire, M. (2013). Turkey-Georgia-Azerbaijan: Trilateralism and the Future of Black Sea Regional Geopolitics. The CACI Analyst. https://www.cacianalyst.org/publications/analytical-articles/item/12837turkey-georgia-azerbaijan-trilat-eralism-and-the-future-of-black-sea-regionalgeopolitics.html

China-Georgia Friendship Celebrates the 25th Anniversary of Diplomatic Relations. Georgia Today (13 June 2017). http://georgiatoday.ge/news/6781/ China-Georgia-Friendship-Celebrates-the-25th-Anniversary-of-DiplomaticRelations-----

China-Georgia FTA. China FTA Network. http://fta.mofcom.gov.cn/topic/ engeorgia.shtml

China and Georgia. Ministry of Foreign Affairs of the People's Republic of China. https://www.fmprc.gov.cn/mfa_eng/wjb_663304/zzjg_663340/dozys_ 664276/gjlb_664280/3170_664312/

China Connects Rail to Europe without Russia as BTK Route Runs South via Caucasus and Turkey. Silk Road Briefing. https://www.silkroadbriefing.com/ news/2018/02/01/china-connects-rail-europe-without-russia-btk-route-runssouth-via-caucasus-turkey/

China - Land Area (sq. Km). Trading Economics. https://tradingeconomics.com/ china/land-area-sq-km-wb-data.html

China Ranks 3rd for Georgia's Wine Exports in 2018. New China. http://www.xinhuanet.com/english/2019-01/06/c_137724201.htm

China's Belt and Road Initiative: Implications for the OSCE. OSCE Network. https://osce-network.net/projects-activities

Chinese Power Company Front-Runner in Anaklia Port Project. Agenda.ge. https://agenda.ge/en/news/2015/2263

Confucius Institute. Free University. http://freeuni.edu.ge/ge/node/703?fbclid= IwAR3LpxU14BjhPkI-niXaJOUrMGTsvnEGfYaxOB0nvFu5GudcbjzRP $0 \mathrm{j} 619 \mathrm{M}$

Confucius Institute at Free University of Tbilisi. Confucius Institutes. http://english.hanban.org/node_13629.htm 
Confucius Institute at Tbilisi Open Teaching University. Confucius Institutes. http://zhuanti.hanban.org/videolist/?cat=379\&tag=en

Confucius Institutes Around the World - 2020. Dig Mandarin. https://www.digmandarin.com/confucius-institutes-around-the-world.html

Construction of Anaklia Deep Sea Port Kicks Off. Agenda.ge. https://agenda.ge/ en/news/2017/2809

Conti Group Reported to be Exiting Anaklia Port Project. PortSEurope. https://www.portseurope.com/conti-group-reported-to-be-exiting-anakliaport-project/

Countries and Regions: Georgia. European Commission. https://ec.europa.eu/ trade/policy/countries-and-regions/countries/georgia/index_en.htm

Daly, J.C.K. (2016). China Deepens its Presence in Georgia via its "One Road, One Belt" Initiative. The CACI Analyst. https://www.cacianalyst.org/publications/ analytical-articles/item/13413-china-deepens-its-presence-in-georgia-via-itsone-road-one-belt-initiative.html

Daly, J.C.K. (2020). Russia's Discreet Satisfaction Over Georgia's Anaklia Port Debacle. Eurasia Daily Monitor, 17(33). https://jamestown.org/program/ russias-discreet-satisfaction-over-georgias-anaklia-port-debacle/

DB and Georgian Railways Agree Cooperation. Railway Pro. https:/www.railwaypro.com/wp/db-and-georgian-railways-agree-cooperation/

Deutsche Bahn and Georgian Railway Sign Agreement Strengthening EuropeanAsian Rail Freight. Railway-News. https://railway-news.com/deutsche-bahnand-georgian-railway-sign-agreement-strengthening-european-asian-railfreight/

Development Issues of Trans-Caspian Int'l Transport Route Discussed in Baku. AzerNews. https://www.azernews.az/business/144190.html

Duchâtel, M., Godement, F., Liik, K., Shapiro, J., Slavkova, L., Stanzel, A., \& Tcherneva, V. (2016). Eurasian Integration: Caught Between Russia and China. European Council on Foreign Relations. https://www.ecfr.eu/article/ essay_eurasian

Ex-PM Ivanishvili to Chair Georgian Dream Party. Civil.ge. https://old.civil.ge/ eng/article.php?id=31047

External Trade of Georgia 2019. Statistical Publication. National Statistics Office of Georgia. https://www.geostat.ge/media/32463/External-MerchandiseTrade-2019_publication-2020.pdf 
Ferdinand, P. (2013). The Positions of Russia and China at the UN Security Council In the Light of Recent Crisis. Briefing Paper, Directorate B, DirectorateGeneral for External Policies of the Union, European Parliament, Belgium. https://www.europarl.europa.eu/RegData/etudes/note/join/2013/433800/ EXPO-SEDE_NT(2013)433800_EN.pdf

Foreign Direct Investments by Countries. National Statistics Office of Georgia. https://www.geostat.ge/en/modules/categories/191/foreign-direct-investments

Frappi, C., \& Valigi, M. (2015). Patters for Cooperation in the Southern Caucasus Area: Azerbaijan, Georgia and Turkey - Triangular Diplomacy in the Shadow of Energy Strategy. Working Paper no. 57, ISPI. https://www.ispionline.it/ sites/default/files/pubblicazioni/wp_57_2015.pdf

Free Trade Agreement, 2007 (the Republic of Turkey, Georgia). https://trade.gov.tr/ data/5b9111f813b8770becf1e74b/3084ba862ac8810125184a17da1112da.pdf

Free Trade Agreements: Georgia. Republic of Turkey Ministry of Trade. https://www.trade.gov.tr/free-trade-agreements/georgia

Galbreath, D., \& Malyarenko, T. (2020) Evolving Dynamics of Societal Security and the Potential for Conflict in Eastern Ukraine, Europe-Asia Studies, 72:2, 209-237, DOI: 10.1080/09668136.2019.1705964

Garibov, A. (2019). Russia Eyes Joining BTK Railway Across South Caucasus. Eurasia Daily Monitor, 16(72). https://jamestown.org/program/ russia-eyes-joining-btk-railway-across-south-caucasus/

Georgia Can Still be a Hub for China, But Only if the Belt \& Road Survives. Belt and Road News. https://www.beltandroad.news/2019/08/29/ georgia-can-still-be-a-hub-for-china-but-only-if-the-belt-road-survives/

Georgia, China Sign Historic Free Trade Agreement. Agenda.ge. https://agenda.ge/ en/news/2017/931

Georgia, EU Sign Association Agreement. Civil Georgia. https://old.civil.ge/eng/ article.php?id=27417

Georgia Exports to China. Trading Economics. https://tradingeconomics.com/ georgia/exports/china

Georgia is the Only Country in the Region Which has Free Trade Agreements with Both the EU and China. FactCheck. https://www.factcheck.ge/en/story/33423georgia-is-the-only-country-in-the-region-which-has-free-trade-agreementswith-both-the-eu-and-china

Georgia Opens its Confucius Institute. China.org.cn. http://www.china.org.cn/ learning_chinese/news/2010-11/27/content_21434619.htm 
Georgia PM Inspects POWERCHINA's Expressway Project. PowerChina. https://en.powerchina.cn/2019-07/18/content_37498243.htm

Georgia, The Observatory of Economic Complexity. OEC. (2018). https://oec.world/en/profile/country/geo

Georgia Welcomes 'Silk Railway' Cargo Train from China to Turkey. Civil Georgia. https://old.civil.ge/eng/article.php?id=28852

Georgian Gov't Cancels Anaklia Development Consortium Contract for Construction of Deep Sea Port on Black Sea Coast. Jam News. https://jam-news.net/georgian-govt-cancels-anaklia-development-consortiumcontract-for-construction-of-deep-sea-port-on-black-sea-coast/

Glurjidze, E., \& Dzamukashvili, S. (2020). The Anaklia Port: A Venture the Georgian Government Can Not Risk? The Institute for a Greater Europe. https://www.institutegreatereurope.com/post/2020/06/17/the-anaklia-port-aventure-the-georgian-government-can-not-risk

Govt Selects Two Final Bidders for Anaklia Deep-Sea Port. Civil Georgia. https://old.civil.ge/eng/article.php?id=28335\&search

GUAM. https://guam-organization.org/en/

How Long Does the Ship from China Sail? ShipHub. https://www.shiphub.co/ how-long-does-the-ship-from-china-sail/

International Cooperation: Profiles. Belt and Road Portal. https://eng.yidaiyilu.gov.cn/info/iList.jsp?site_id=CMSydylyw\&cat_ id $=10076 \&$ cur_page $=1$

Jensen, T.-P., \& Vana, T. Rail Transport Has Become More Competitive in Speed and Cost. Tschudi Logistics. https://tschudilogistics.com/rail-transportchina-cis-europe/

Johnson, R.F. (2020). Why Ukraine is a Secret Weapon for China's Airpower. Middle East Institute. https://www.mei.edu/publications/ why-ukraine-secret-weapon-chinas-airpower

JSC Partnership Fund. Invest in Georgia. https://www.investingeorgia.org/en/ keysectors/energy/access-to-finance/jsc-partnership-fund

JSC Partnership Fund. LinkedIn. https://ge.linkedin.com/company/jscpartnership-fund

Josephs, J. (2017). All Aboard the China-to-London Freight Train. BBC News. https://www.bbc.co.uk/news/business-38654176 
Kenderdine, T. (2018). Caucasus Trans-Caspian Trade Route to Open China Import Markets. East Asia Forum. https://www.eastasiaforum.org/2018/02/23/ caucasus-trans-caspian-trade-route-to-open-china-import-markets/

Larsen, J. (2017a). Commentary: Georgia-China relations are about more than economics. Civil Georgia. https://old.civil.ge/eng/article.php?id=30514

Larsen, J. (2017b). Georgia-China Relations: The Geopolitics of the Belt and Road. Policy Paper, Georgian Institute of Politics (GIP): Tbilisi. http:/gip.ge/ georgia-china-relations-geopolitics-belt-road/

Larsen, J. (2017c). Georgia: The Black Sea Hub for China's 'Belt and Road. The Diplomat. https://thediplomat.com/2017/05/georgia-the-black-sea-hubfor-chinas-belt-and-road/

Leijen, M. van (2019). Volumes on Middle Corridor to Increase Fourfold in 2019. RailFreight.com. https://www.railfreight.com/beltandroad/2019/01/22/ volumes-on-middle-corridor-to-increase-fourfold-in-2019/?gdpr=accept

Lomsadze,G.(2019a).InGeorgianPolitics,It'sMillionairevsBillionaire.Eurasianet. https://eurasianet.org/in-georgian-politics-its-millionaire-vs-billionaire

Lomsadze, G. (2019b). Undeterred by slow start, Georgia woos Chinese investors. Eurasianet. https://eurasianet.org/undeterred-by-slow-start-georgia-wooschinese-investors

Mardell, J. (2019). On the 'Middle Corridor,' China Is Largely Absent. Berlin Policy Journal. https://berlinpolicyjournal.com/on-the-middle-corridor-chinais-largely-absent/

Meeting Asia's Infrastructure Needs. Asian Development Bank, Mandaluyong City, Philippines. https:/www.adb.org/sites/default/files/publication/227496/ special-report-infrastructure.pdf

Members of the Association are commercial and non-commercial organizations, which are interested in cooperation with the Association and in contributing to the development of its activity. Middlecorridor.com. https://middlecorridor.com/en/association-members/regular-members

Menabde, G. (2015). China Seeks Massive Investments in Georgia. Eurasia Daily Monitor, 12(55). https://jamestown.org/program/china-seeks-massiveinvestments-in-georgia/

Menabde, G. (2016). China Loses Bid for Construction of Georgian Deep-Water Port on Black Sea. Eurasia Daily Monitor, 13(39). https://jamestown.org/program/ china-loses-bid-for-construction-of-georgian-deep-water-port-on-black-sea/ 
Menabde, G. (2019a). Russia Tries to Bog Down the Anaklia Deep Sea Port Project. Eurasia Daily Monitor, 16(73). https://jamestown.org/program/ russia-tries-to-bog-down-the-anaklia-deep-sea-port-project/

Menabde, G. (2019b). Georgia's Anaklia Deep-Water Port Faces a New Challenge. Eurasia Daily Monitor, 16(88). https://jamestown.org/program/georgiasanaklia-deep-water-port-faces-a-new-challenge/

Middle Corridor. https://middlecorridor.com/en

Miholjcic, N. (2018). Trans-Caspian International Transportation Route: A Way to Steadfast Economic Development and Connectivity in the South Caucasus and Central Asia. Journal of the Ministry of Foreign Affairs of the Republic of Azerbaijan, 49, 134-140.

Muller, N. (2018). Georgian Coal Town Longs for Chinese Rescue. Eurasianet. https://eurasianet.org/georgian-coal-town-longs-for-chinese-rescue

New Records Set on the Middle Corridor to Turkey. RailFreight.com. https://www.railfreight.com/beltandroad/2020/07/06/new-records-set-on-themiddle-corridor-to-turkey/?gdpr=accept

Opening of the 26th China Lanzhou Investment and Trade Fair. People's Daily Online. http://finance.people.com.cn/n1/2020/0703/c1004-31769307.html [Translated from Chinese to English via Google Translate].

Partnership Fund. www.fund.ge

Past Events: The 'Trans-Caspian East-West Trade \& Transit Corridor' Forum", 26-27 June 2017. CPC - Caspian Policy Centre. https://www.caspianpolicy. org/the-trans-caspian-east-west-trade-transit-corridor-forum/

PM Discusses Georgia-China Partnership at Beijing University. Government of Georgia.http://gov.ge/index.php?lang_id=ENG\&sec_id=412\&info_id=51429

PM Garibashvili: 'we will start selecting new potential investor for Anaklia Deep Sea Port project in near future' Agenda.ge. https://agenda.ge/en/news/2021/583

Project of the Century' Anaklia Deep Sea Port will be Built by 2020. Agenda.ge. https://agenda.ge/en/news/2016/2373

Putin and Xi: Not Quite the Allies They Seem. Financial Times. https://www.ft.com/content/cd637c7e-f4a8-11e4-8a42-00144feab7de

Putz, C. (2016). Why The Trans-Caspian Transport Route Matters. The Diplomat. https://thediplomat.com/2016/02/why-the-trans-caspian-transportroute-matters/ 
Republic of Georgia Selects Anaklia Development Consortium to Build a Deep Sea Port in Anaklia. BusinessWire. https://www.businesswire.com/news/home/20160208005531/en/RepublicGeorgia-Selects-Anaklia-Development-Consortium-Build

Rukhadze, V. (2015). Georgia's Anaklia Port May Alter Balance of Power Near Russian-Occupied Abkhazia. Eurasia Daily Monitor, 12(120). https://jamestown.org/program/georgias-anaklia-port-may-alter-balance-ofpower-near-russian-occupied-abkhazia/

Silk Road Chengdu-Europe Express Rail-Connecting the World. Realogistics. http://www.realogistics.net/index.php/en/show/76-tab-13-en-chengdu-europeexpress-rail/387-chengdu-europe-express-rail

TBC Holding, Conti Joint Venture Awarded Anaklia Deep-Sea Port Project. Civil Georgia. https://old.civil.ge/eng/article.php?id=28966

TITR. TRACECA. http://www.traceca-org.org/md/countries/kazakhstan/thetransport-logistics-sector-of-the-republic-of-kazakhstan/trans-caspianinternational-transport-route/

Topuria, R. (2019). Georgia Can Still Be a Hub for China, But Only If the Belt and Road Survives. The Diplomat. https://thediplomat.com/2019/08/ georgia-can-still-be-a-hub-for-china-but-only-if-the-belt-and-road-survives/

Topuria, R. (2016). Georgia: The Key to China's 'Belt and Road'. The Diplomat. https://thediplomat.com/2016/04/georgia-the-key-to-chinas-belt-and-road/

Uatkhanov, Y. (2017). Kazakhstan, Azerbaijan and Georgia Sign TransCaspian International Transport Route Protocol. The Astana Times. https://astanatimes.com/2017/04/kazakhstan-azerbaijan-and-georgia-signtrans-caspian-international-transport-route-protocol/

Ukraine, China to Deepen Ties: Ukrainian Deputy PM. XinhuaNet. http://www.xinhuanet.com/english/2020-07/25/c_139239988.htm

Ukraine Expects New Infrastructure Projects from Belt and Road Forum: Deputy Minister. New China. http://www.xinhuanet.com//english/2017-05/01/c 136247844.htm

US-Based Conti Group 'Confirms Intention to Exit' Anaklia Development Consortium. Agenda.ge. https://agenda.ge/en/news/2019/2886

US-Based Conti Group Not to Leave Anaklia Development Consortium. Agenda.ge. https://agenda.ge/en/news/2019/2881

Uysal, O. (2014). 10 Things to Know About Baku-Tbilisi-Kars Railway Project. Rail Turkey En. https://railturkey.org/2014/10/20/baku-tblisi-kars-railway/ 
Van Dijk, M.P., \& Martens, P. (2016). The Silk Road and Chinese Interests in Central Asia and the Caucasus: The Case of Georgia". Conference Paper, MSM 2016 Research conference, Maastricht, The Netherlands. https://www.researchgate.net/publication/325271343_The_Silk_Road_and Chinese_interests_in_Central_Asia_and_the_Caucasus_the_case_of_Georgia

Will Georgia Still Build the Ambitious Anaklia Port? New Tender in the Works. Jam News. https://jam-news.net/will-georgia-still-build-the-ambitiousanaklia-port-new-tender-in-the-works/

Xinhua Headlines: Railway Freight Express Puts China-EU Cooperation Amid Pandemic on Fast Track. XinhuaNet. http://www.xinhuanet.com/english/202006/27/c_139170811.htm

Zalinger, B. (2020). Perspectives Arbitrations are not a good look for Georgia. Eurasianet. https://eurasianet.org/perspectives-arbitrations-are-not-a-goodlook-for-georgia

Zhen, L. (2017). Can a China-Moldova Free-Trade Deal Give Beijing a Foothold in Eastern Europe?" South China Morning Post. https:/www.scmp.com/news/china/diplomacy-defence/article/2126179/ can-china-moldova-free-trade-deal-give-beijing-foothold

\section{Кемоклідзе Н. Китайська ініціатива “Один пояс, один шлях”: можли- вості та виклики для Грузії. - Стаття.}

У цій статті досліджується зростаюча присутність і діяльність Китаю у Грузії, а також їх нинішні і потенційні геополітичні наслідки. Мета статті полягає у сприянні кращому розумінню китайської ініціативи “Один пояс, один шлях" та іiі впливу на соціально-політичну, економічну, екологічну і військову безпеку у Грузії, а також більш широкі наслідки для стійкої стабільності у Кавказькому регіоні у цілому. У статті підкреслюється роль Грузії у BRI як суходольного та морського “мосту”. Крім того, докладно розглядається роль Транскаспійського маршруту, т.зв. “Середнього коридору” і його складника - залізниці Баку-ТбілісіКарс (БТК) - у майбутній розвиток BRI і участі Грузії у ньому в якості “логістичного вузла", що поєднує Азію та Європу. Також у статті досліджуються перспективи проекту глибоководного порту у чорноморському місті Анаклія у Грузії і те, чому він до сих пір не реалізований. Проект зачіпає конфліктуючі інтереси Росії, Туреччини і США, і вплив геополітики на економічні розрахунки проекту є показовим. Стаття значною мірою грунтується на дослідженні, проведеному влітку і восени 2020 року, в аналізі використовуються як вторинні, так і первинні джерела, матеріали інтернет-інтерв'ю і спілкування автора 3 представниками уряду Грузії, представниками посольства, експертами у цій сфері, 
грузинськими студентами по обміну у Китаї та іншими особами, пов'язаними 3 китайськими компаніями у Грузії. У статті показано, як, незважаючи на посилення китайської участі у Грузії у цілому, інтерес Китаю до розвитку економічно i, можливо, політично стратегічного для Грузії маршруту "Середній коридор" залишається досить низьким. Однак, як показано у статті, це не повинно перешкодити Грузії реалізувати свій амбітний план з перетворення на суходольний та морський “вузол” у регіоні. Китай, безсумнівно, є важливим гравцем в Азії і за ії межами, але далеко не єдиним.

Ключові слова: ініціатива “Один пояс, один шлях”, китайсько-грузинські відносини, “Середній коридор”, залізниця Баку-Тбілісі-Карс, порт Анаклія.

\section{Кемоклидзе Н. Китайская инициатива “Один пояс, один путь":} возможности и вызовы для Грузии. - Статья.

В данной статье исследуется растущее присутствие и деятельность Китая в Грузии, а также их нынешние и потенциальные геополитические последствия. Цель статьи состоит в способствовании лучшему пониманию китайской инициативы “Один пояс, один путь" и ее влияния на социально-политическую, экономическую, экологическую и военную безопасность в Грузии, а также более широкие последствия для устойчивой стабильности в Кавказском регионе в целом. В статье подчеркивается роль Грузии в BRI как сухопутного и морского “моста". Кроме того, подробно рассматривается роль Транскаспийского маршрута, т.н. “Среднего коридора" и составляющей его железной дороги Баку-Тбилиси-Карс (БТК) в будущем развитии BRI и участия Грузии в нем в качестве “логистического узла", соединяющего Азию и Европу. Также в статье исследуются перспективы проекта глубоководного порта в черноморском городе Анаклия в Грузии и то, почему он до сих пор не реализован. Проект затрагивает конфликтующие интересы России, Турции и США, и влияние геополитики на экономические расчеты проекта показательно. Статья в значительной степени основана на исследовании, проведенном летом и осенью 2020 года, в анализе используются как вторичные, так и первичные источники, материалы интернет-интервью и общения автора с представителями правительства Грузии, представителями посольства, экспертами в этой области, грузинскими студентами по обмену в Китае и другими лицами, связанными с китайскими компаниями в Грузии. В статье показано, как, несмотря на усиление китайского участия в Грузии в целом, интерес Китая к развитию экономически и, возможно, политически стратегического для Грузии маршрута "Средний коридор" остается достаточно низким. Однако, как показано в статье, это не должно помешать Грузии реализовать свой амбициозный план по превращению 
в сухопутный и морской “узел” в регионе. Китай, несомненно, является важным игроком в Азии и за ее пределами, но далеко не единственным.

Ключевые слова: инициатива "Один пояс, один путь”, китайско-грузинские отношения, “Средний коридор”, железная дорога Баку-Тбилиси-Карс, порт Анаклия. 